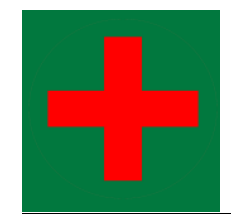

\title{
Pengaruh Promosi Kesehatan Mengenai Covid-19 terhadap Kualitas Hidup Masyarakat
}

\author{
M Dana Prihadi ${ }^{1}$, Chicy Indah Sari ${ }^{2}$ \\ ${ }^{1}$ program Diploma III Rekam Medis dan Informatika Kesehatan Akademi Perekam \\ Medis Dan Informatika Kesehatan Bandung, Indonesia \\ Email: ${ }^{1}$ danaprihadi@ apikesbandung.ac.id, ${ }^{2}$ ChicyIS@apikesbandung.ac.id
}

\begin{abstract}
COVID-19 is a new disease that causes infection in the human respiratory tract and has a fairly high transmission rate. The problem related to this disease is the lack of public awareness in implementing a healthy lifestyle for the prevention and transmission of COVID-19. One way to gain knowledge and insight regarding the application of a healthy lifestyle is to organize health promotion through visual media and print media that are distributed to patients in the Cibogo Community Health Center, Subang Regency. Health promotion that is intensified through visual media and print media is expected to encourage people to capture, understand and remember the messages conveyed in the media, so that lifestyles can change according to science. This study uses a quantitative approach in which the calculation results will be described descriptively. There were 94 questionnaires distributed, each of which consisted of 13 statements. Based on research findings, health promotion through digital media attracts more public attention through print media. In addition, quality of life, in this study, is public awareness in implementing health protocols and implementing them in daily life.
\end{abstract}

Keywords: Promotion, Health, Covid, Quality Life

\begin{abstract}
Abstrak
Penyakit Covid-19 merupakan penyakit baru yang mengakibatkan infeksi pada saluran pernapasan manusia serta memiliki tingkat penularan cukup tinggi. Permasalahan yang muncul yaitu kurangnya kesadaran masyarakat dalam menerapkan pola hidup sehat mengenai pencegahan penularan virus Covid-19. Untuk memperoleh pengetahuan dan wawasan mengenai penerapan pola hidup sehat salah satunya dengan cara menyelenggarakan promosi kesehatan melalui media visual dan media cetak yang disebarkan pada pasien dilingkungan Puskesmas Cibogo Kab. Subang. Melalui promosi menggunakan media visual dan media cetak, masyarakat diharapkan dapat mudah menangkap, memahami, dan mengingat pesan-pesan yang disampaikan dalam media tersebut sehingga dapat mempengaruhi perubahan pola hidup yang berdasarkan pengetahuan. Penelitian ini menggunakan pendekatan kuantitatif kemudian hasil perhitungan akan dijelaskan secara deskriptif. Jumlah kuesioner yang disebar sebanyak 94 kuesioner dengan 13 pernyataan. Berdasarkan penelitian yang dilakukan menunjukan bahwa promosi kesehatan menggunakan media digital lebih menarik perhatian masyarakat jika dibandingkan dengan menggunakan media cetak. Sedangkan kualitas
\end{abstract}


hidup yang dimaksud disini adalah kesadaran dalam menjalankan protokol kesehatan dan masyarakat sudah menerapkannya dalam kehidupan sehari-hari.

Kata Kunci: Promosi, Kesehatan, Covid, Kualitas Hidup

\section{PENDAHULUAN}

Pandemi Covid-19 merupakan salah satu penyakit virus global yang mempengaruhi kondisi berbagai negara. Awal mula ditemukannya kasus Covid-19yaitu di kota Wuhan China yang kemudian menyebar ke berbagai belahan dunia. World Healt Organization (WHO) pertama kali mengumumkan kemunculan virus Covid-19 pada bulan Januari 2020. Penyakit Covid atau Coronavirus Desease 2019 (Covid-19) disebabkan oleh Severe Acute Respiratory Syndrome Coronavirus 2 (SARS-CoV-2) (Lai et al., 2020). Penyakit Covid-19 merupakan penyakit baru yang mengakibatkan infeksi pada saluran pernapasan manusia serta memiliki tingkat penularan cukup tinggi (Ciotti et al., 2020; Pilkington et al., 2020).

Angka kasus positif Covid-19 dari bulan Januari - Mei di Kabupaten Subang terus meningkat, kondisi ini dapat disebabkan oleh beberapa hal diantaranya; kurangnya kesadaran masyarakat dalam menerapkan pola hidup sehat serta kurangnya pengetahuan masyarakat mengenai pencegahan penularan Covid-19 seperti menjaga jarak (physical distancing), mencuci tangan pakai sabun, memakai masker apabila hendak keluar rumah, menghindari kerumunan, menerapkan protokol kesehatan dalam menerima barang dari kurir, dan menerapkan pola hidup sehat untuk menjaga imunitas tubuh agar tidak mudah sakit.

Salah satu upaya yang dapat dilakukan untuk menekan angka penyebaran Covid-19 yaitu dengan pendidikan kesehatan. Pendidikan kesehatan merupakan aplikasi atau penerapan pendidikan di bidang kesehatan. Secara oprasional pendidikan kesehatan adalah semua kegiatan untuk memberikan dan meningkatkan pengetahuan sikap, praktek baik individu, kelompok ataupun masyarakat dan meningkatkan kesehatan mereka sendiri (Notoatmodjo, 2012). Penggunaan strategi promosi kesehatan diharapkan dapat berdampak pada peningkatan kualitas hidup masyarakat (Atmajanti et al., 2020). Promosi kesehatan meupakan upaya untuk meningkatkan kemampuan masyarakat melalui pembelajaran dari, oleh, untuk, dan bersama masyarakat, agar mereka dapat menolong diri sendiri, dan mengembangkan kegiatan yang bersumber daya masyarakat, sesuai sosial budayasetempat serta didukung kebijakan publik yang berwawasan kesehatan (Asharo et al., 2021).

Hasil penelitian sebelumnya yang dilakukan (Martanto, 2007) menyatakan bahwa penggunaan media visual terbilang efektif jika dibandingkan dengan media audio. Sedangkan, kombinasi dari kedua media tersebut, yaitu berupa penggunaan media audio visual, terbukti sangat efektif dalam mempengaruhi perilaku kesehatan. Dalam hal ini, perilaku kesehatan baik erat kaitannya dengan proses penerimaan informasi yang diberikan . pemberian informasi merupakan salah satu strategi utama yang diterapkan oleh WHO untuk memperoleh perubahan perilaku (Notoatmodjo, 2012). Menurut bapak Yuniko selaku ketua penyelenggara promosi kesehatan Puskesmas Cibogo menyatakan bahwa, promosi kesehatan rutin dilakukan melalui penyuluhan keliling dan penyuluhan langsung kepada masyarakat. Tetapi untuk mengetahui apakah terdapat pengaruh dari kegiatan promosi kesehatan, belum dilakukan penelitian dengan analisis pasti hanya berdasarkan respon masyarakat saja.

Penelitian yang akan penulis lakukan memiliki permasalahan yang akan dibatasi, yaitu mengenai pengaruh promosi kesehatan terhadap peningkatan kualitas hidup masyarakat, serta jenis media promosi dan cara penyampaian yang seperti apa yang akan mempengaruhi wawasan individu. Adapun media yang digunakan dalam penelitian ini yaitu media visual dan media cetak. Berdasarkan batasan-batasan tersebut, maka permasalahan yang akan dijawab dalam penelitian ini secara jelas akan tercakup dalam rumusan masalah berikut ini: Adakah pengaruh 
promosi kesehatan terhadap kualitas hidup masyarakat? Seberapa besar pengaruh promosi kesehatan terhadap peningkatan kualitas hidup masyarakat? Media seperti apa yang dapat menarik minat masyarakat sehingga dapat meningkatkan kualitas hidup menjadi lebih baik?. Menurut permasalahan yang telah dileliti serta latar belakang yang telah diuraikan diatas maka peneliti tertarik untuk meniliti "Pengaruh Promosi Kesehatan Mengenai Covid-19 Terhadap Kualitas Hidup Masyarakat Dilingkungan Puskesmas Cibogo Kab. Subang”.

\section{METODE}

Penelitian ini menggunakan pendekatan kuantitatif (Sugiyono, 2017). Hasil penelitian yang diperoleh berupa data-data numerikal yang akan diolah serta dianalisis secara statistikal dengan menggunakan perhitungan yang telah ditetapkan. Kemudian hasil perhitungan tersebut akan dijelaskan secara deskriptif, yaitu dengan menjelaskan keadaan yang sebenarnya berdasarkan hasil dari data yang diperoleh. Adapun metode yang digunakan dalam penelitian ini adalah metodepenelitian eksperimental yang bertujuan untuk menyelidiki adanya kemungkinan hubungan sebab akibat. Populasi yang diambil dalam penelitian ini yaitu seluruh pasien yang datang berobat ke Puskesmas Cibogo Kab.Subang pada periode Januari, Februari dan Maret 2021 dengan jumlah populasi sebanyak 1.806 pasien dengan rata-rata sebanyak 602 pasien per bulan. Jumlah sampel yang dijadikan objek dalam penelitian ini adalah sejumlah 94 responden dengan menggunakan simple random sampling.

Penelitian dilakukan di Puskesmas Cibogo Subang selama 2 bulan dimulai pada bulan 08 Maret 2021 s/d 19 Mei 2021. Hasil dari dapat yang diperoleh dihitung menggunakan menggunakan Software Statistical Program For Sosial Science (SPSS). Dalam penelitian ini penulis menggunakan teknik pengumpulan data dengan observasi, kuesioner (angket), dan dokumentasi. Untuk mengetahui tingkatan pencapaian responden (TCR) digunakan rumus sebagai berikut:

$T C R=\frac{\text { Rata-rata skor } x 100}{\text { Skor maksimum }}$

Reliabilitas adalah alat ukur yang menunjukan bahwa alat ukur yang digunakan dalam penelitian mempunyai keandalan sebagai alat ukur, diantaranya diukur melalui konsistensi hasil pengukuran dari waktu ke waktu jika fenomena yang diukur tidak berubah (Zulganef, 2006). Bagian ini menjelaskan tentang jenis penelitian diantaranya jenis penelitian kuantitatif ata kualitatif, Penelitian kualitatif seperti studi kasus, fenomenologi, etnografi, dan lain-lain, perlu menambahkan uraian mengenai pengecekan keabsahan hasil penelitian. Penelitian kuantitatif menjelaskan lokasi dan waktu penelitian, populasi dan sampel, teknik sampling, teknik pengumpulan data, analisis data, dan penyajian data. Penelitian yang menggunakan alat dan bahan, perlu menuliskan spesifikasi alat dan bahan yang digunakan. Penulisan menggunakan Times New Roman 12pt (tegak) dengan spasi 1. Tiap paragraf diawali dengan Indentasi $1 \mathrm{~cm}$ dan tidak boleh menggunakan pengorganisasian penulisan ke dalam "anak sub-judul" pada bagian ini. Ditampilkan dalam 1-2 paragraf.

Nomor halaman, persamaan matematis. Naskah dicantumkan nomor halaman. Persamaan matematis ditulis menggunakan Equation Editor atau sejenisnya. Setiap variabel dalam persamaan diberi keterangan saat pertama kali variabel tersebut muncul. Seluruh persamaan dituliskan di tengah, dengan nomor urut persamaan diletakkan rata kanan dan rumus ditulis secara dengan indeks seperti rumus 1 . 


$$
\begin{aligned}
& \Delta F=-2,3 \times 10^{6} \times F^{2} \frac{\Delta M}{A} \\
& \Delta F=-2,3 \times 10^{6} \times F^{2} \frac{\Delta M}{A}
\end{aligned}
$$

\section{HASIL}

Uji yang pertama yaitu uji validitas yang berguna untuk menguji apakah instrument tersebut valid sehingga dapat digunakan untuk pengujian selanjutnya. Validitas dengan kriteria jika Rhitung > Rtabel maka pernyataan dinyatakan valid, jika Rhitung < Rtabel maka pernyataan dinyatakan tidak valid.

Tabel 1. Uji Validitas

\begin{tabular}{|c|c|c|c|}
\hline $\begin{array}{c}\text { No Item } \\
\text { Pernyataan }\end{array}$ & Rhitung & Rtabel & Keterangan \\
\hline 1 & 0.788 & 0.207 & Valid \\
\hline 2 & 0.731 & 0.207 & Valid \\
\hline 3 & 0.759 & 0.207 & Valid \\
\hline 4 & 0.717 & 0.207 & Valid \\
\hline 5 & 0.861 & 0.207 & Valid \\
\hline 6 & 0.728 & 0.207 & Valid \\
\hline 7 & 0.654 & 0.207 & Valid \\
\hline 8 & 0.662 & 0.207 & Valid \\
\hline 9 & 0.656 & 0.207 & Valid \\
\hline 10 & 0.823 & 0.207 & Valid \\
\hline 11 & 0.722 & 0.207 & Valid \\
\hline 12 & 0.843 & 0.207 & \\
\hline 13 & 0.863 & 0.207 & \\
\hline
\end{tabular}

Berdasarkan hasil uji validitas menunjukan bahwa nilai korelasi tiap item pernyataan dengan total skor yang diperoleh lebih besar dari 0,207 sehingga dapatdisimpulkan bahwa item pernyataan yang digunakan adalah valid dan dapat digunakan dalam analisis data selanjutnya. Pengujian reliabilitas menggunakan Alfa Cornbach dilakukan untuk instrumen yang memiliki jawaban lebih dari 1 (Adamson \& Prion, 2013). Instrumen yang dimaksud misalnya berbentuk esai, angket, atau kuesioner. Menurut (Streiner, 2003) mengungkapkan bahwa instrumen dikatakan reliabel jika koefisien reliabilitas Alfa Cornbach lebih dari 0.70 (R1 > 0.70). Adapun hasil pengujian reliabilitas yang dilakukan dengan menggunakan program SPSS dengan jumlah responden 94 orang adalah sebagai berikut:

Tabel 2. Uji Reliabilitas

\begin{tabular}{|c|c|}
\hline Cronbach's Alpa & N Of Item \\
\hline .891 & 13 \\
\hline
\end{tabular}

Berdasarkan hasil uji reliabilitas table 2 yang dilakukan terhadap semua item dalampenelitian ini dapat dikatakan reliabel dengan nilai Cronbach's Alpa sebesar 0.891 karena lebih besar dari 0.70 .

Tabel 3. Kategori Responden Berdasarkan Jenis Kelamin

\begin{tabular}{|c|c|c|c|c|c|}
\hline \multicolumn{2}{|c|}{ Jenis_Kelamin } \\
\hline \multicolumn{2}{|c|}{} & Frequency & Percent & $\begin{array}{c}\text { Valid } \\
\text { Percent }\end{array}$ & $\begin{array}{c}\text { Cumulative } \\
\text { Percent }\end{array}$ \\
\hline \multirow{3}{*}{ Valid } & Laki-Laki & 20 & 21,3 & 21,3 & 21,3 \\
\cline { 2 - 6 } & Perempuan & 74 & 78,7 & 78,7 & 100,0 \\
\cline { 2 - 6 } & Total & 94 & 100,0 & 100,0 & \\
\hline
\end{tabular}

Berdasarkan tabel 3, diketahui bahwa responden yang berjenis kelamin perempuan lebih banyak dari responden yang berjenis kelamin laki-laki yaitu jumlah responden perempuan 74 orang sedangkan laki-laki sebanyak 20 orang. 
Tabel 4. Kategori Responden Berdasarkan Pendidikan

\begin{tabular}{|c|c|c|c|c|c|}
\hline \multicolumn{2}{|c|}{} & Frequency & Percent & $\begin{array}{c}\text { Valid } \\
\text { Percent }\end{array}$ & $\begin{array}{c}\text { Cumulative } \\
\text { Percent }\end{array}$ \\
\hline \multirow{4}{*}{} & SD & 4 & 4,3 & 4,3 & 4,3 \\
\cline { 2 - 6 } & SMP & 15 & 16,0 & 16,0 & 20,2 \\
\cline { 2 - 6 } & SMA & 67 & 71,3 & 71,3 & 91,5 \\
\cline { 2 - 6 } & D3 & 1 & 1,1 & 1,1 & 92,6 \\
\cline { 2 - 6 } & S1 & 7 & 7,4 & 7,4 & 100,0 \\
\cline { 2 - 6 } & Total & 94 & 100,0 & 100,0 & \\
\hline
\end{tabular}

Berdasarkan tabel 4, dapat diketahui kategori responden berdasarkan pendidikan, yaitu sebanyak 4 orang adalah lulusan SD, sebanyak 15 orang adalah lulusan SMP, sebanyak 67 orang adalah lulusan SMA, sebanyak 1 orang lulusan diploma 3, sebanyak 7 orang lulusan sarjana.

Tabel 5. Kategori Responden Berdasarkan Usia

\begin{tabular}{|c|c|c|c|c|c|}
\hline \multicolumn{6}{|c|}{ Umur } \\
\hline & & Frequency & Percent & $\begin{array}{c}\text { Valid } \\
\text { Percent }\end{array}$ & $\begin{array}{c}\text { Cumulative } \\
\text { Percent }\end{array}$ \\
\hline \multirow{25}{*}{ Valid } & 17 & 1 & 1,1 & 1,1 & 1,1 \\
\hline & 19 & 7 & 7,4 & 7,4 & 8,5 \\
\hline & 20 & 4 & 4,3 & 4,3 & 12,8 \\
\hline & 21 & 5 & 5,3 & 5,3 & 18,1 \\
\hline & 22 & 11 & 11,7 & 11,7 & 29,8 \\
\hline & 23 & 6 & 6,4 & 6,4 & 36,2 \\
\hline & 24 & 10 & 10,6 & 10,6 & 46,8 \\
\hline & 25 & 5 & 5,3 & 5,3 & 52,1 \\
\hline & 26 & 6 & 6,4 & 6,4 & 58,5 \\
\hline & 27 & 5 & 5,3 & 5,3 & 63,8 \\
\hline & 28 & 4 & 4,3 & 4,3 & 68,1 \\
\hline & 29 & 2 & 2,1 & 2,1 & 70,2 \\
\hline & 30 & 1 & 1,1 & 1,1 & 71,3 \\
\hline & 31 & 1 & 1,1 & 1,1 & 72,3 \\
\hline & 32 & 4 & 4,3 & 4,3 & 76,6 \\
\hline & 33 & 2 & 2,1 & 2,1 & 78,7 \\
\hline & 34 & 2 & 2,1 & 2,1 & 80,9 \\
\hline & 36 & 1 & 1,1 & 1,1 & 81,9 \\
\hline & 38 & 5 & 5,3 & 5,3 & 87,2 \\
\hline & 39 & 3 & 3,2 & 3,2 & 90,4 \\
\hline & 45 & 3 & 3,2 & 3,2 & 93,6 \\
\hline & 46 & 1 & 1,1 & 1,1 & 94,7 \\
\hline & 47 & 1 & 1,1 & 1,1 & 95,7 \\
\hline & 48 & 1 & 1,1 & 1,1 & 96,8 \\
\hline & 49 & 1 & 1,1 & 1,1 & 97,9 \\
\hline
\end{tabular}

Berdasarkan table sarkan tabel 4.5 dilihat dari 94 responden yang terdiri dari 8 orang tahun, 58 orang berusia 20-29 tahun, 19 orang berusia 30-39 tahun, 7 orang berusia 40-49 tahun, 2 orang berusia $>50$ tahun. Dapat disimpulkan bahwapasien berusia 20-29 tahun lebih banyak dari pada pasien lainnya.

Tabel 6. Analisa Tanggapan Responden Mengenai Promosi Kesehatan

\begin{tabular}{|l|c|c|c|c|c|c|c|c|l|}
\hline No & Pernyataan & \multicolumn{5}{|c|}{ Jawaban } & Skor & \multirow{2}{*}{ TCR } \\
\cline { 2 - 8 } & STS & TS & CS & S & ST & & & \\
\hline Promosi Kesehatan & \multicolumn{2}{|l|}{} & & & \\
\hline & Iklan mengenai covid-19 & & & & & & & \\
\hline
\end{tabular}




\begin{tabular}{|c|l|c|c|c|c|c|c|c|c|}
\hline 1 & 0 & 1 & 4 & 38 & 51 & 94 & 421 & $89 \%$ \\
\hline 2 & $\begin{array}{l}\text { dapat menambah } \\
\text { pengetahuan }\end{array}$ & 0 & 4 & 4 & 49 & 37 & 94 & 401 & $85 \%$ \\
\hline $\begin{array}{l}\text { Iklan menggunakanmedia } \\
\text { menarik }\end{array}$ & $\begin{array}{l}\text { Iklan menggunakanmedia } \\
\text { cetak dapat } \\
\text { menambah wawasan }\end{array}$ & 0 & 3 & 6 & 57 & 28 & 94 & 392 & $83 \%$ \\
\hline 4 & $\begin{array}{l}\text { Sarana dan fasilitas yang } \\
\text { digunakan petugas } \\
\text { puskesmas sudah memadai } \\
\text { dalam } \\
\text { memberikan penanganan } \\
\text { covid-19pada masyarakat }\end{array}$ & 0 & 1 & 4 & 53 & 36 & 94 & 406 & $86 \%$ \\
\hline 5 & $\begin{array}{l}\text { Penyuluhan petugas } \\
\text { puskesmas dapat menambah } \\
\text { pengetahuan mengenai covid- } \\
19\end{array}$ & 0 & 1 & 4 & 48 & 41 & 94 & 411 & $87 \%$ \\
\hline 6 & $\begin{array}{l}\text { Mengetahui perkembangan } \\
\text { covid-19 jenis terbaru } \\
\text { melalui penyuluhan }\end{array}$ & 0 & 0 & 9 & 43 & 42 & 94 & 409 & $87 \%$ \\
\hline 7 & $\begin{array}{l}\text { Keresahan masyarakat } \\
\text { mengenai simpang siurberita } \\
\text { covid-19 dapat terjawab } \\
\text { apabila ada } \\
\text { penyuluhan }\end{array}$ & 0 & 0 & 4 & 45 & 45 & 94 & 417 & $89 \%$ \\
\hline
\end{tabular}

Berdasarkan tabel 6, dapat diketahui bahwa dari pernyataan mengenai promosi kesehatan, jumlah skor ideal untuk seluruh item yaitu 5 x $94=470$ (jika semua responden menjawab sangat baik), maka dari 94 responden dapat disimpulkan bahwa pernyataan penelitian ke-1 berjumlah 421 maka tingkat persetujuannya yaitu $(421: 470) \times 100 \%=89 \%$, ke-2 berjumlah 401 maka tingkat persetujuannya yaitu $(401: 470) \times 100 \%=85 \%$, ke-3 berjumlah 392 maka tingkat persetujuannya yaitu $(392: 470) \times 100 \%=83 \%$, ke-4 berjumlah 406 maka tingkat persetujuannya yaitu (406: 470) x 100\% = 86\%, ke-5 berjumlah 411 maka tingkat persetujuannya yaitu (411: 470) x $100 \%=87 \%$, ke-6 berjumlah 409 maka tingkat persetujuannya yaitu (409: 470) x 100\% = 87\%, ke-7 berjumlah 417 maka tingkat persetujuannya yaitu $(417: 470) \times 100 \%=89 \%$. Dapat disimpulkan bahwa pernyataan mengenai promosi kesehatan terhadap tanggapan responden memiliki kategori rata-rata $(89+85+83+86+87+87+89) / 7=86,5 \%$ dalam tabel klasifikasi TCR angka tersebut menunjukan sangat baik.

Tabel 7. Analisa Tanggapan Responden Mengenai Kualitas Hidup

\begin{tabular}{|c|c|c|c|c|c|c|c|c|c|}
\hline \multirow[t]{2}{*}{ No } & \multirow[t]{2}{*}{ Pernyataan } & \multicolumn{5}{|c|}{ Jawaban } & \multirow[t]{2}{*}{$\mathbf{N}$} & \multirow[t]{2}{*}{ Skor } & \multirow[t]{2}{*}{ TCR } \\
\hline & & STS & TS & CS & $\mathbf{S}$ & ST & & & \\
\hline \multicolumn{10}{|c|}{ Kualitas Hidup } \\
\hline 1 & $\begin{array}{l}\text { Sering mencuci } \\
\text { tangan memakai } \\
\text { sabun }\end{array}$ & 0 & 0 & 1 & 17 & 76 & 94 & 451 & $96 \%$ \\
\hline 2 & $\begin{array}{l}\text { Menggunakan } \\
\text { masker ketika keluar } \\
\text { rumah }\end{array}$ & 0 & 0 & 1 & 14 & 79 & 94 & 454 & $97 \%$ \\
\hline 3 & $\begin{array}{l}\text { Menjaga jarak dan } \\
\text { menghindari } \\
\text { kerumunan }\end{array}$ & 0 & 0 & 5 & 22 & 67 & 94 & 438 & $93 \%$ \\
\hline 4 & Melakukan vaksinasi & 0 & 1 & 22 & 44 & 27 & 94 & 379 & $81 \%$ \\
\hline 5 & $\begin{array}{l}\text { Melakukan rapid-test } \\
\text { apabila menunjukan } \\
\text { gejala covid-19 }\end{array}$ & 0 & 0 & 8 & 37 & 49 & 94 & 417 & $89 \%$ \\
\hline
\end{tabular}




\begin{tabular}{|c|l|c|c|c|c|c|c|c|c|}
\hline 6 & $\begin{array}{l}\text { Melakukan isolasi } \\
\text { mandiri apabila } \\
\text { menunjukan gejala } \\
\text { covid-19 }\end{array}$ & 0 & 1 & 6 & 35 & 52 & 94 & 420 & $89 \%$ \\
\hline
\end{tabular}

Berdasarkan tabel 7, dapat diketahui bahwa dari pernyataan mengenai kualitas hidup, jumlah skor ideal untuk seluruh item yaitu 5 x $94=470$ ( jika semuaresponden menjawab sangat baik), maka dari 94 responden dapat diketahui bahwapernyataan penelitian ke-1 berjumlah 451 maka tingkat persetujuannya yaitu $(451: 470) \times 100 \%=96 \%$, ke-2 berjumlah 454 maka tingkat persetujuannya yaitu $(454: 470) \times 100 \%=97 \%$, ke-3 berjumlah 438 maka tingkat persetujuannya yaitu $(438: 470) \times 100 \%=93 \%$, ke-4 berjumlah 379 maka tingkat persetujuannya yaitu (379: 470) x $100 \%=81 \%$, ke-5 berjumlah 417 maka tingkat persetujuannya yaitu (417:470) x $100 \%=89 \%$, ke-6 berjumlah 420 maka tingkat persetujuannya yaitu $(420: 470) \times 100 \%=89 \%$. Dapat disimpulkan bahwa pernyataan mengenai kualitas hidup terhadap tanggapan responden memiliki kategori rata-rata (96+ $97+93+81+89+89) / 6=91 \%$ dalam tabel klasifikasi TCR angka tersebut menunjukan sangat baik.

Untuk mengetahui apakah hipotesis diterima atau ditolak, maka untukmenguji apakah ada hubungan yang signifikan antara variabel $\mathrm{X}$ dengan variabel $\mathrm{Y}$ menggunakan statistik uji $\mathrm{f}$. tingkat signifikansi yang digunakan dalam penelitian ini yaitu 0,05 , dengan derajat keabsahan $\mathrm{df}$ $=94-2=92$. Dimana nilai $\mathrm{f}$ tabel yaitu 3,94. Adapun hasil pengujian secara uji statistik dapat dilakukan dengan membandingkan jika Fhitung > Ftabel maka hipotesis diterima, apabila Fhitung $<$ Ftabel maka hipotesis ditolak.

Tabel 8. Hasil Pengujian

\begin{tabular}{|c|c|c|c|c|c|c|}
\hline \multicolumn{2}{|c|}{ Model } & $\begin{array}{c}\text { Sum of } \\
\text { Squares }\end{array}$ & df & $\begin{array}{c}\text { Mean } \\
\text { Square }\end{array}$ & F & Sig. \\
\hline \multirow{3}{*}{1} & Regression & 193,776 & 1 & 193,776 & 37,099 & $.000^{\mathrm{b}}$ \\
\cline { 2 - 6 } & Residual & 480,533 & 92 & 5,223 & & \\
\cline { 2 - 6 } & Total & 674,309 & 93 & & & \\
\hline a. Dependent Variable: kualitas_hidup \\
\hline b. Predictors: (Constant), promosi_kesehatan \\
\hline \multicolumn{7}{|c|}{ Model Summary } \\
\hline Model & R & R Square & $\begin{array}{c}\text { Adjusted } \\
\text { R Square }\end{array}$ & Std. Error of the Estimate \\
\hline 1 & $.536^{\text {a }}$ & 0,287 & 0,280 & \\
\hline
\end{tabular}

Dari output tersebut diketahui bahwa nilai $\mathrm{F}$ hitung $=37.099$ jika dibandingkan dengan $\mathrm{F}$ tabel maka $\mathrm{F}$ hitung $(37,099)>\mathrm{F}$ tabel $(3,94)$ dengan tingkat signifikansi $0.000<0.05$, diketahui bahwa dasar pengambilan keputusan signifikansi yaitu membandingkan nilai signifikansi dengan nilai probabilitas $(0,05)$. Jika nilai signifikansi $<0,05$ maka terdapat pengaruh dari variabel bebas terhadap variabel terikat. Diketahui koefisien determinasi ( $R$ square) sebesar 0.280, maka dapat disimpulkan bahwa terdapat pengaruh variabel independen (Promosi Kesehatan) terhadap variabel dependen (Kualitas Hidup) sebesar 28\% dimana angka tersebut dalam interpretasi nilai $r$ dinyatakan rendah.

\section{PEMBAHASAN}

Dalam penelitian ini rata-rata responden berjenis kelamin perempuan yang mencapai $78,8 \%$, Jenis kelamin perempuan memiliki jiwa berorientasi pada tugas dan memiliki sifat komperitif hal ini berbanding terbalik pada jenis kelamin laki- laki. Selain itu perempuan memiliki sifat yang rajin teliti dan tekun akan suatu hal. Maka dengan sikap yang dimiliki 
menunjukan bahwa perempuan memiliki tingkatpengetahuan yang jauh lebih baik dibandingkan dengan laki-laki (Suwaryo \& Yuwono, 2017). Untuk kriteria umur rata-rata responden berumur diantara 20-29 tahun dengan presentase 61,7\%, pasien berusia 20-29 tahun lebih banyak dari padapasien lainnya, karena pasien pada usia produktif lebih mengetahui teknologi dan informasi melalui media digital sehingga memiliki wawasan yang lebih luas dan tingkat kesadaran yang tinggi. Angka pertumbuhan penggunaan internet di Indonesia masih didominasi kalangan muda usia 15-30 tahun. Untuk pendidikan terakhir mayoritas responden memiliki pendidikan sekolah menengah atas sebanyak $71 \%$, dapat disimpulkan bahwa kurangnya tingkat pendidikan, pemahaman serta kesadaran masyarakat dapat menyebabkan masyarakat tidak mengetahui bagaimana cara menyikapi covid-19 (Diarti et al., 2017). Penelitian ini terdiri dari variabel independen yaitu promosi kesehatan dan variabeldependen yaitu kualitas hidup. Dari jawaban pernyataan responden mengenai promosi kesehatan, dapat disimpulkan bahwa iklan menggunakan media digital lebih unggul $2 \%$ dibandingkan iklan menggunakan media cetak. Berdasarkan survey yang dilakukan oleh Assosiasi Penyelenggara Jasa Internet Indonesia (APPJII), diperoleh informasi bahwa jumlah pengguna internet di Indonesia mencapai 171,17 juta jiwa pada tahun 2018 dan 19,1\% dari pengguna internet di indonesia menggunakan media sosial, penggunaan media sosial ini merupakan alasan seseorang menggunakan internet. Pernyataan mengenai kualitas hidup terhadap tanggapan responden memiliki kategori rata-rata 91\% dalam tabel klasifikasi TCR angka tersebut menunjukan sangat baik. Dari presentase diatas dapat disimpulkan bahwa masyarakat sudah setuju bahkan menjalankan protokol kesehatan dalam kehidupan sehari-hari, hal ini menandakan tingkat kesadaran masyarakat sudah tinggi.

\section{KESIMPULAN DAN SARAN}

Hasil pengujian dilakukan menunjukan bahwa terdapat pengaruh promosi kesehatan terhadap kualitas hidup hidup masyarakat sebesar $28 \%$. Hasil pengukuran presentase pengaruh promosi kesehatan sebesar $86,5 \%$ responden menyatakan setuju bahwa promosi kesehatan memiliki pengaruh terhadap peningkatan pengetahuan dan cara menghadapi covid-19. Pengukuran presentase kualitas hidup sebesar 91\% responden menyatakan setuju dan siap menjalankan protokol kesehatan dalam kehidupan sehari- hari. Hasil analisa tanggapan responden mengenai promosi kesehatan, iklan menggunakan media digital memiliki presentase sebesar $85 \%$ sedangkan iklan media cetak memiliki presentase sebesar 83\%, dalam hal ini iklan melalui media digital lebih unggul sebesar $2 \%$ dapat disimpulkan bahwa mayarakat lebih tertarik dengan iklan melalui media digital dibandingkan dengan iklan melalui media cetak. Maka dari itu hipotesis mengenai terdapat pengaruh promosi kesehatan terhadap peningkatan kualitas kesehatan dengan melakukan penyuluhan menggunakan media visual dan media cetak dinyatakan diterima. Hal ini didukung oleh penelitian (Aditya Dwi Martanto, 2007) bahwa penggunaan jenis media dalam kegiatan promosi kesehatan khususnya media digital dapat terbilang efektif dalam mempengaruhi kualitas hidup masyarakat.

\section{DAFTAR PUSTAKA}

Adamson, K. A., \& Prion, S. (2013). Reliability: Measuring internal consistency using Cronbach's $\alpha$. Clinical Simulation in Nursing, 9(5), e179-e180.

Asharo, R. K., Arifiyanto, A., Khaleyla, F., \& Rahmadi, C. T. (2021). Wawasan Perilaku Hidup Bersih dan Sehat (PHBS) di Masa Kenormalan Baru dalam Upaya Mencegah Penyebaran Covid-19 di Lingkungan Sekolah. Mitra Mahajana: Jurnal Pengabdian Masyarakat, 2(2), 184-192.

Atmajanti, C. I., Richtiara, G. C., Az-Zahra, D., Sophia, N. A., \& Rahmawati, P. A. (2020). Edukasi Protokol Kesehatan New Normal dan Pengenalan Dunia Bisnis di Tengah Pandemi Covid-19 Melalui Media Sosial. Jurnal Layanan Masyarakat (Journal of Public Services), 4(2), 472-478.

Ciotti, M., Ciccozzi, M., Terrinoni, A., Jiang, W.-C., Wang, C.-B., \& Bernardini, S. (2020). The COVID-19 pandemic. Critical Reviews in Clinical Laboratory Sciences, 57(6), 365388 . 
Diarti, E., Sutriningsih, A., \& Rahayu, W. (2017). Hubungan antara penggunaan internet dengan gangguan pola tidur pada mahasiswa PSIK Unitri Malang. Nursing News: Jurnal Ilmiah Keperawatan, 2(3).

Lai, C.-C., Shih, T.-P., Ko, W.-C., Tang, H.-J., \& Hsueh, P.-R. (2020). Severe acute respiratory syndrome coronavirus 2 (SARS-CoV-2) and coronavirus disease-2019 (COVID-19): The epidemic and the challenges. International Journal of Antimicrobial Agents, 55(3), 105924.

Martanto, A. D. (2007). Pengaruh media promosi kesehatan terhadap perilaku kesehatan: Studi eksperimental pada remaja pelajar SMUN 27 Jakarta.

Notoatmodjo, S. (2012). Metodologi penelitian kesehatan.

Pilkington, V., Pepperrell, T., \& Hill, A. (2020). A review of the safety of favipiravir-a potential treatment in the COVID-19 pandemic? Journal of Virus Eradication, 6(2), 4551.

Streiner, D. L. (2003). Being inconsistent about consistency: When coefficient alpha does and doesn't matter. Journal of Personality Assessment, 80(3), 217-222.

Sugiyono. (2017). Metode Penelitian Kuantitatif, Kualitatif, dan R\&D. CV Alfabeta.

Suwaryo, P. A. W., \& Yuwono, P. (2017). Faktor-faktor yang mempengaruhi tingkat pengetahuan masyarakat dalam mitigasi bencana alam tanah longsor. URECOL, 305314.

Zulganef, P. P. S. (2006). Aplikasinya menggunakan AMOS 5. Bandung: Penerbit Pustaka. 